\title{
$\mathrm{PH} 100$ accualitad
}

\section{Jaén acoge la próxima conferencia internacional sobre paisajes rurales europeos PECSRL 2020}

\begin{abstract}
Jaén y Baeza son las ciudades sede de la 29 edición de la veterana Permanent European Conference for the Study of the Rural Landscape (PECSRL). Encuentro bianual que viene celebrándose desde 1957 para la discusión de investigadores de distintos ámbitos científicos interesados en el estudio de los paisajes rurales europeos. La cita es en septiembre y el título: Living together in European Rural Landscapes. Esta ocasión el análisis y discusión remarcan, entre otros aspectos, la importancia, en las dinámicas actuales de la mayoría de los espacios rurales europeos, de encontrarse bajo un mismo ámbito de regulación, la Política Agraria Común.
\end{abstract}

Antonia Paniza Cabrera | Área de Geografía Física, Universidad de Jaén

Url de la contribución <www.iaph.es/revistaph/index.php/revistaph/article/view/4617>

Los paisajes rurales atesoran una gran riqueza cultural y patrimonial reflejo de la evolución que han sufrido a lo largo de la historia; son el resultado de los cambios acaecidos por su propia dinámica natural y de los distintos pueblos que los han poblado y los pueblan actualmente. Ello ha supuesto la generación de unos espacios únicos y que, como consecuencia de procesos recientes, se están viendo afectados y, en muchas ocasiones, degradados. Estos cambios tienen raíz natural, por ejemplo, derivados del cambio climático, y/o antrópico, resultado de la presencia de una economía cada vez más globalizada, que está suponiendo cambios en los usos, en los pobladores y en las estructuras que presentan los espacios rurales europeos. Esto implica a menudo la pérdida de su personalidad, sus manifestaciones culturales y actividades tradicionales que, ante la falta de rentabilidad y de renovación poblacional, se están viendo avocadas a la desaparición.

El interés por los espacios rurales ya se vislumbraba a mediados del siglo XX y fue el origen de las primeras reuniones de la Permanent European Conference for the Study of the Rural Landscape (PECRSL), lugar de encuentro y discusión de investigadores de distintos ámbitos científicos interesados en el estudio de los paisajes rurales europeos. Resultado de ello son las reuniones periódicas que se celebran cada dos años desde 1957 por los miembros de esta red de trabajo, en la que, con diversas actividades científicas, sesiones de comu-

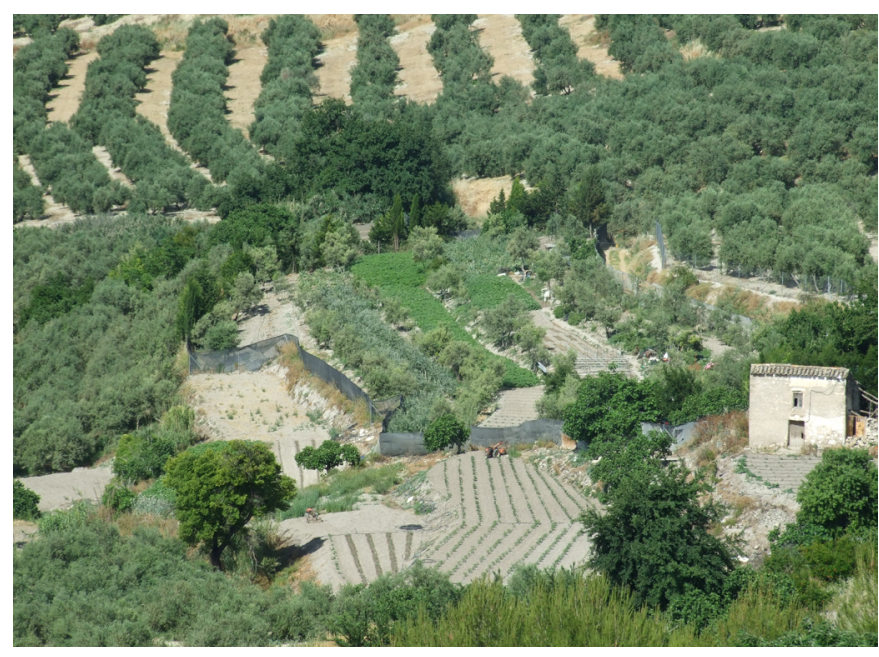

Huertas tradicionales de Úbeda (Jaén) | fotos Antonia Paniza, autora de todas las imágenes

nicaciones y ponencias, mesas redondas, salidas de campo (con el fin de conocer los paisajes rurales donde tiene lugar el congreso), etc., se debate y presentan trabajos de investigación centrados en los espacios rurales europeos. Las temáticas de discusión son muy amplias y diversas, están enfocadas en estudios interdisciplinares que tienen su eje de interés en las dinámicas que han afectado a los espacios rurales tanto en el pasado como en el presente y en su evolución futura. Consecuencia de ello, las disciplinas implicadas en el PECSRL abarcan todos aquellos campos de conocimiento que tiene relación con los estudios paisajísticos: historia, 


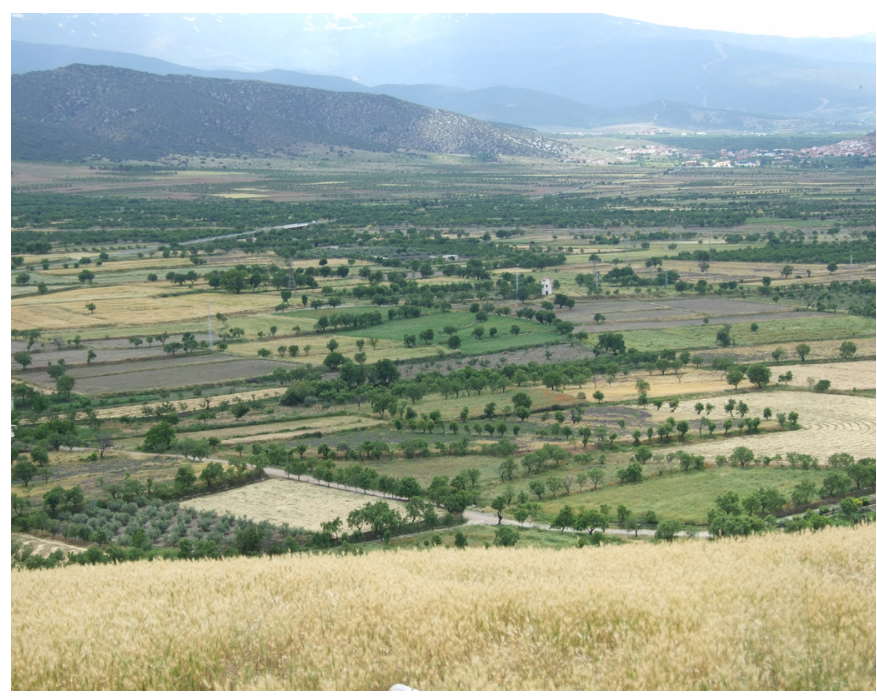

Cultivos en la zona del Marquesado del Zenete (Granada)

geografía, arte, biología, arquitectura, antropología, etc. Un elemento de gran interés es la posibilidad que ofrece el desarrollo del congreso del PECSRL de cooperación entre los investigadores y los gestores del paisaje, generando una interesante plataforma para plantear proyectos conjuntos que ayuden al desarrollo y a la supervivencia de los paisajes rurales $y$, junto a ello, al mantenimiento de la población que se asienta en el espacio rural y que son los responsables últimos de la conservación o destrucción de este rico patrimonio natural y cultural.

El congreso se celebra, como hemos citado anteriormente, cada dos años en un país diferente de Europa y es organizado por alguno de los miembros del PECSRL. La estructura que tradicionalmente presenta la conferencia es la celebración de varias sesiones de trabajo en dos localidades. Los primeros dos días se suelen celebrar en la ciudad que es sede de la institución donde trabajan los encargados de organizar el congreso, el tercer día se desarrollan diferentes salidas de campo que muestran a los asistentes los paisajes rurales de la zona que acoge a los conferenciantes. Los recorridos finalizan en la segunda sede del congreso que suele ser un espacio con un carácter predominantemente rural.

Las últimas tres sesiones se han celebrado en Gothenburg y Mariestad (Suecia, 2014), Innsbruck y Seefeld (Austria, 2016) y Clermont-Ferrand y Mende (Francia,
2018). Las temáticas respectivas de estas ediciones fueron Descifrando la lógica de los paisajes, Montaña, tierras altas, tierras bajas, paisajes europeos desde una perspectiva altitudinal y Paisajes europeos y calidad de vida.

Bajo el título Living together in European Rural Landscapes se celebra en las ciudades de Jaén y Baeza la 29 edición de la Permanent European Conference for the Study of the Rural Landscape. En esta ocasión se centra en el análisis y discusión de aquellos elementos que conviven e interaccionan actualmente en los paisajes europeos, de las relaciones que presentan con otros espacios, remarcando en este caso la importancia que presentan en las dinámicas actuales el que, en su mayoría, los espacios rurales europeos se encuentran bajo un mismo ámbito de regulación, la Política Agraria Común.

El tema general se divide en cinco líneas temáticas:

1. Viviendo juntos con o contra la naturaleza y el cambio climático en los paisajes naturales, rurales y urbanos.

2. Viviendo junto a otros pueblos y culturas (locales, inmigrantes, turistas, extranjeros, vecinos, etc.) en el paisaje.

3. Conviviendo con el pasado social, económico, cultural y patrimonial.

4. Viviendo juntos frente a procesos futuros, dinámicas y cambios en el paisaje.

5. Investigaciones y avances científicos en formas sostenibles, democráticas y participativas de convivencia: teoría, metodología, herramientas y políticas.

Un tema igualmente importante en esta edición es la celebración durante 2020 del 20 aniversario de la Convención Europea del Paisaje, con lo cual es una de las temáticas destacadas del congreso.

Más información:

http://www.pecsrl.org/NextConference.html

http://eventos.ujaen.es/29754/detail/29-session-of-permanenteuropean-conference-for-the-study-of-the-rural-landscape.html 